\title{
Topicality as War News Value: A Pragma - Linguistic Study
}

\author{
Fareed Hameed Al-Hindawi \\ Dept. of English, College of Education for Humanities, Babylon University, Iraq \\ E-mail: fareedhameed3@gmail.com
}

Hussein Huwail Ghayadh (Corresponding author)

General Directorate of Education in Thiqar, Iraq

E-mail: huwailhussein@gmail.com

\author{
Received: 20-03-2017 \\ Accepted: 17-05-2017 \\ Advance Access Published: July 2017 \\ Published: 01-09-2017 \\ doi:10.7575/aiac.ijalel.v.6n.5p.279 \\ URL: http://dx.doi.org/10.7575/aiac.ijalel.v.6n.5p.279
}

\begin{abstract}
This paper discusses one of the criteria of war news values in printed media. The current study concerns itself with only Topicality as the target of scrutiny. It explores this value through the application of a model of analysis based on a pragma-linguistic approach. The analysis is intended to achieve the following aims: first, bringing topicality as one criterion of news values to the attention of pragmatists; second, introducing an analytical framework which is hoped to be useful for pragmatists to analyze news values, and to be available in their hands for further development. This framework aims at explicitly revealing the linguistic as well as the pragmatic properties of the war news texts as far as topicality is concerned. In relation to the aims of the study and owing to the fact that people are eager to understand what is going on, it is hypothesized that topicality comes into viewable interaction between grammar and pragmatics. The findings of the data analysis indicate how topicality is transferred to the receiver of the message and how it shapes news reporting.
\end{abstract}

Keywords: News Values, Topicality, Existential Constructions, Restrictive Modifiers, Pragmatic Slack, War News, Apposition

\section{Introduction}

People show a widespread desire to share and know about news from elsewhere, which they satisfy by traveling, talking to each other and sharing information. One of the basic questions news journalism students ask is "What is news?" Answering this question requires having sufficient knowledge in the field in addition to the ability to recognize the notion itself.

In journalism, news is a research topic just as relevance is in information science. Thus, various definitions of the issue are suggested. For example, the American Heritage Dictionary of the English Language defines news as "information about recent events or happenings, especially as reported by newspapers, periodicals, radio, or television. Similarly, Stephens (1997: 13) points out that a journalism history text defines news as "new information about a subject of some public interest that is shared with some portion of the public". However, Farrell (2010: 2) states that the most quoted definition of news is commonly attributed to Charles A. Dana. Charles A. Dana who ran the New York Sun from 18691897defines news as, "anything that interests a large part of the community and has never been brought to its attention before."

In an earlier endeavor to define the word' news', Stephens (1997: 13) believes that it typically connotes the presentation of new information. Prior to that, Salmon (1923: 10) affirms that the newness of news gives it an uncertain quality which distinguishes it from the more careful investigations of history or other scholarly disciplines, whereas historians, he (ibid) proceeds, tend to view events as causally related manifestations of underlying processes, news stories tend to describe events in isolation, and to exclude discussion of the relationships between them. News conspicuously describes the world in the present or immediate past, even if the most important aspects of news story occurred long time ago-or are expected to occur in the future.

Behind the news story, the most important concept an inexperienced reporter must learn is the task of making news have values and deciding who to talk to with this news, what to write about, what to prioritize, and how to present those values in their news reports as will be illustrated later in this work. These aspects of news reporters' prerequisite knowledge have prompted this work to set itself the task of investigating how news values, ' topicality' in particular, can play a vital role in war news reporting in addition to identifying the pragma-linguistic strategies used for realizing it, i.e. topicality. This involves developing an analytical framework for attaining the aforementioned aims in the data under study. 


\section{War News}

War is found in the behaviour and nature of man. Wars arise from misdirected violent impulses, from egoism, from brainlessness. These are the main causes of wars; others are secondary and have to be interpreted in the light of these common factors. Hence, as sustained by the work of Niebuhr (1937: 158), war has its origin in "dark, unconscious sources in the human psyche." Prior to that but in the same tradition, James (1910: 22) views war as rooted in man's bellicose nature, which is the product of centuries-old tradition. In line with this view, the issue is argued most clearly and cogently by Durbin and Bowlby (1939: 41). According to them, war takes place due to the expression in and through group life of the transformed aggressiveness of individuals.

It is important ; however, to emphasize that newspapers, magazines, television, radio and the internet are critical for the way we interpret the events outside of our direct environment and they inform what is known as 'symbolic sphere of our existence' (Gerbner et al., 1986: 37). Equally important to this is the use of press, posters, pamphlets and films accompanied by organized lectures, patriotic clubs and rallies to support the armed conflict (Jowett and O'Donnell, 1999: 27).

In addition to the arguments mentioned above, there is a point which is worth $t$ considering. Foucault (1972: 52) hypothesizes that in every society the production of discourse, spoken or written, is at once controlled, selected, organized and re- distributed according to a certain number of procedures, whose role is "to avert its powers and its dangers, to cope with chance events, to evade its ponderous, awesome materiality." Van Dijk (1988: 2) states that "discourse is not simply an isolated textual or dialogic structure. Rather, it is a complex communicative event that also embodies a social context, featuring participants (and their properties) as well as a production and reception process". Following this, Schechter (2003: 39) points out that Aaron Brown of CNN, after September 11 $1^{\text {th }}$ attacks on the World Trade Center and the Pentagon, declares that "All of our lives have been changed today." This piece of discourse is war news. To put it another way, it, i.e. war news, can be considered as discourse structures (also known as text structures). It can be defined as the "knowledge structures or basic rhetorical patterns in texts" (Grabe, 2003: 9). These structures are the frameworks that writers, especially media writers, employ to convey valuable information in an organized and coherent manner. As a result, texts are generally organized according to certain basic rhetorical patterns (Hoey, 2001: 61).

\section{News Values}

News values are the decisive factors in deciding how much distinguished a news story is considered by a media egress, and the awareness it is given by a group of listeners. Conley \& Lamble (2006: 42) state that news values determine whether stories are to be pursued. They determine whether, if pursued, they will then be published. They determine, if published, where the stories will be placed in news presentation. Having been placed, new values will determine to what extent the public will read them [Italics are ours]. News values are worth studying because they inform the mediated world that it is presented to news audiences, and provide a shared shorthand operational understanding of what working journalists are required to produce to deadlines (Harcup \& O’Neill, 2016: 1). Weaver et al. (2007) point out that news values can less be seen as a reflection of what type of information citizens want or need, and more as a reflection of organizational, sociological and cultural norms combined with economic factors (cited in Harcup \& O'Neill, 2016: 4).

A fairly large number of books on news and journalism contain sections which either attempt to codify and define news values, or review previous attempts to do so. It is believed by this study that having a look at some of these preceding endeavours is necessary to set the scene, take account of, or provide the underlying basis for our own analysis, and give or provide us with what is necessary for accomplishing a task or satisfying a need to see how the authors' own backgrounds tend to determine which kind of news values analysis they should conduct.

Broadly speaking, different studies classify news values into more than one kind. Brighton and Foy (2007: 5) point out that news values tend to be of two kinds. The first one examines news stories from the perspective of the working journalist, and tries to isolate the features of an event which make it likely to be qualified as newsworthy. The second one attempts to take a broader approach - incorporating areas such as ideology, cultural conditioning, technological determinism and others. They ( ibid ) argue that a third approach is needed in conjunction with these two existing schools of thought. This third approach is necessary because of changes within individual media, and because of a shift in the nature of the relationships between providers and consumers of news.

Additionally, Bell (1991: 155) puts forward that news values can be recognized and identified through analysis of journalistic textbooks or by "deduction from what actually happens in the media". For Bell (ibid: 247), news values "drive the way news stories are gathered, structured and presented". Furthermore, he (ibid) gives an account or representation of news values as "the - often unconscious - criteria by which news workers make their professional judgments as they process stories".

Similarly, Cotter (2010: 67-73) seems to attribute a clear mono-causal, uni-directional relationship, with news values influencing or governing news practice, shaping or becoming embedded in text. In addition, she (ibid: 75) argues that news values function as guidelines for decision-making and are invoked, unconsciously or explicitly, at every step of the news process. News values are one of the most important practice-based and ideological factors in understanding the focus and shape of news stories and the decisions of journalists. To summarize lists of news values from six newswriting textbooks, Table 1 below shows how these values are distributed over the selected textbooks: 
Table 1. News values distributed over textbooks

\begin{tabular}{|c|c|c|c|c|c|c|}
\hline $\begin{array}{l}\text { News Values } \\
\text { (Textbook } \\
\text { Classification) }\end{array}$ & Textbook 1 & Textbook 2 & Textbook 3 & Textbook 4 & Textbook 5 & Textbook 6 \\
\hline News Value 1 & Topicality & Impact & Timeliness & Timeliness & Timeliness & Timeliness \\
\hline News Value 2 & Relevance & Proximity & Impact & Proximity & Proximity & Proximity \\
\hline News Value 3 & Composition & Timeliness & Prominence & conflict & Prominence & prominence \\
\hline News Value 4 & Expectation & Prominence & Proximity & $\begin{array}{l}\text { Eminence \& } \\
\text { prominence }\end{array}$ & Currency & Rarity \\
\hline News Value 5 & Unusualness & $\begin{array}{l}\text { Novelty or } \\
\text { deviance }\end{array}$ & Conflict & $\begin{array}{l}\text { Consequence \& } \\
\text { impact }\end{array}$ & Drama & Human interest \\
\hline News Value 6 & Worth & Conflict & $\begin{array}{l}\text { The unusual } \\
\text { Currency } \\
\text { (Conscience) }\end{array}$ & Human interest & $\begin{array}{l}\text { Consequence } \\
\text { Novelty }\end{array}$ & \\
\hline News Value 7 & $\begin{array}{l}\text { External } \\
\text { influences }\end{array}$ & & & & & \\
\hline $\begin{array}{l}\text { Authors \& } \\
\text { Publishing } \\
\text { Year }\end{array}$ & $\begin{array}{l}\text { Brighton \& Foy } \\
2007\end{array}$ & $\begin{array}{l}\text { Bunton et al. } \\
1999\end{array}$ & $\begin{array}{l}\text { Mencher 1997, } \\
2006\end{array}$ & $\begin{array}{l}\text { Itule \& Anderson } \\
1991\end{array}$ & $\begin{array}{l}\text { Lorenz \& } \\
\text { Vivian } 1996\end{array}$ & Hough 1988 \\
\hline
\end{tabular}

News values such as proximity, timeliness and prominence are key news values, in the "top four" of each textbook listed in Table $\mathbf{1}$, as well as in the "top three" in Textbooks $\mathbf{5}$ and $\mathbf{6}$. Topicality and timeliness, simply, are whether the story is new or old, or relevant in some way to the calendar (holiday or anniversary stories, for instance). Prominence gauges the standing of the individual under news scrutiny (a well- known person is of news interest). Proximity is the extent to which the story has occurred locally or, if it has occurred elsewhere, is relevant to readers locally (federal government edicts with local impacts, for instance). Noteworthy, the news value of conflict is high on the list of only one textbook (Itule and Anderson 1991), near the end or not present in the other cases (Mencher 1997 and 2006; Hough 1988; Lorenz and Vivian 1996), and at the very bottom of another (Bunton et al. 1999). Similarly, the news value of impact (or consequence) is high on two of the lists and in second to the last position on the other two, and absent in (Hough 1988). In addition, news criteria such as topicality, relevance, composition, expectation, worth and external influences are mentioned only in Textbook 1(Brighton \& Foy 2007).

\subsection{Topicality}

While evaluating the consistency of news values tackled in different criteria, Brighton and Foy (2007: 29) narrow the list even more and reduce it to seven values which, in their view, reflect the recent changes in media and better suit the modern media sphere. These narrowed news values are:

1. Topicality (i.e. something that is new, current and immediately relevant)

2. Relevance (i.e. the significance of an item to the viewer, listener or reader.)

3. Composition (i.e. the need for balance in news)

4. Expectation (i.e. what the consumer expects)

5. Unusualness (i.e. unusual behaviour, unexpected events/doings)

6. Worth (i.e. news about elite people and organizations, and about celebrities)

7. External influences (i.e. pressures from outside) (ibid).

This study concerns itself with the first criterion of news values, i.e. topicality in terms of Brighton and Foy's (2007) classification.

Topicality means immediacy of the event. Sometimes, journalists suggest that the word news exactly means 'things which are new'. It could also be said that topics which are current are good news. Viewers, readers, or listeners are used to receive the latest updates, and there is so much news about old news which is quickly discarded, that is, it's no longer interesting. It is important to note however, that recent events have higher news value than earlier happenings. Furthermore, it is important however to overemphasize the strengths of immediacy in media. It is a temporal concept which refers to the time which has elapsed between the occurrence of an event and its reporting as a news story.

This already discussed point is sustained by the work of Schlesinger (1987). He (ibid, 39) points out that topicality is related to the speed with which coverage can be mounted. The pure type of immediacy, therefore, is 'live' broadcasting. In such cases, a TV camera or radio car is at the scene of the event as it happens, and the event is transmitted immediately to the viewer or listener. An additional implication is the notion that the audience for news, can, via the technical means of communication, be present at the event. This idea is obviously fostered by contemporary broadcasting technology and the possibility of providing up-to-date actuality. There is, however, a further point to be considered. Newspapers, by comparison, cannot be 'immediate' in this sense. They can, however, try to approach the ideal of rapid turn-over by rapidly updating stories in successive editions. What is of more concerns to this work is what 
is affirmed by Clamons et al (1999: 59) who view topicality as a pragmatic property. In the same trend, Givón (2001: 198) stresses that topicality is grammaticalized inside the clause.

\section{Data Analysis}

\subsection{Data}

The data which are intended to be analyzed by this study are limited to War News about war in Iraq as reported by the BBC, New York Times, and News Week Magazine. The data under scrutiny consist of three different sources; the first was broadcasted by BCC News Satellite Channel under the title "Comprehensive and critical analysis of the 1990-1991 war, TIME: 3:48:22". Second, New York Times (an American daily newspaper) two articles, one is entitled "Pentagon Report on Persian Gulf War: A Few Surprises and Some Silences", whereas the second is entitled "After the War: The President; Transcript of President Bush's Address on End of the Gulf War". Third, News Week Magazine (an American weekly news magazine), two articles, first, is entitled "Crisis in the Gulf: War Path.", whereas the second is entitled "Looking Back at Desert Storm". All these sources (see References) are concerned with the Gulf War 1991.

\subsection{Analysis}

\subsubsection{Methods of Analysis}

As suggested above, topicality is one of influential types of news values. There are pragmatic levels and some grammatical structures of discourse which give a first impression of how topicality and its various structures may link up with some aspects of war news values. In most cases, we can trace the creation of grammatical forms in general to external motivations. According to a large number of linguists (Roodney Huddleston, 2002; Paulline Jacobson and Geoffrey K. Pullum1985) the proposal that grammar is motivated is valid. To put it simpler, we can argue that all grammar is pragmatically motivated; i. e. there is some sort of correspondence between forms and functions. The extent of pragmatic motivation of grammar can be observed by the analysis conducted below by means of the analytical model adapted from Brighton and Foy's (2007) according to the notions discussed in the previous sections. This model is schematized by Figure 1 below.
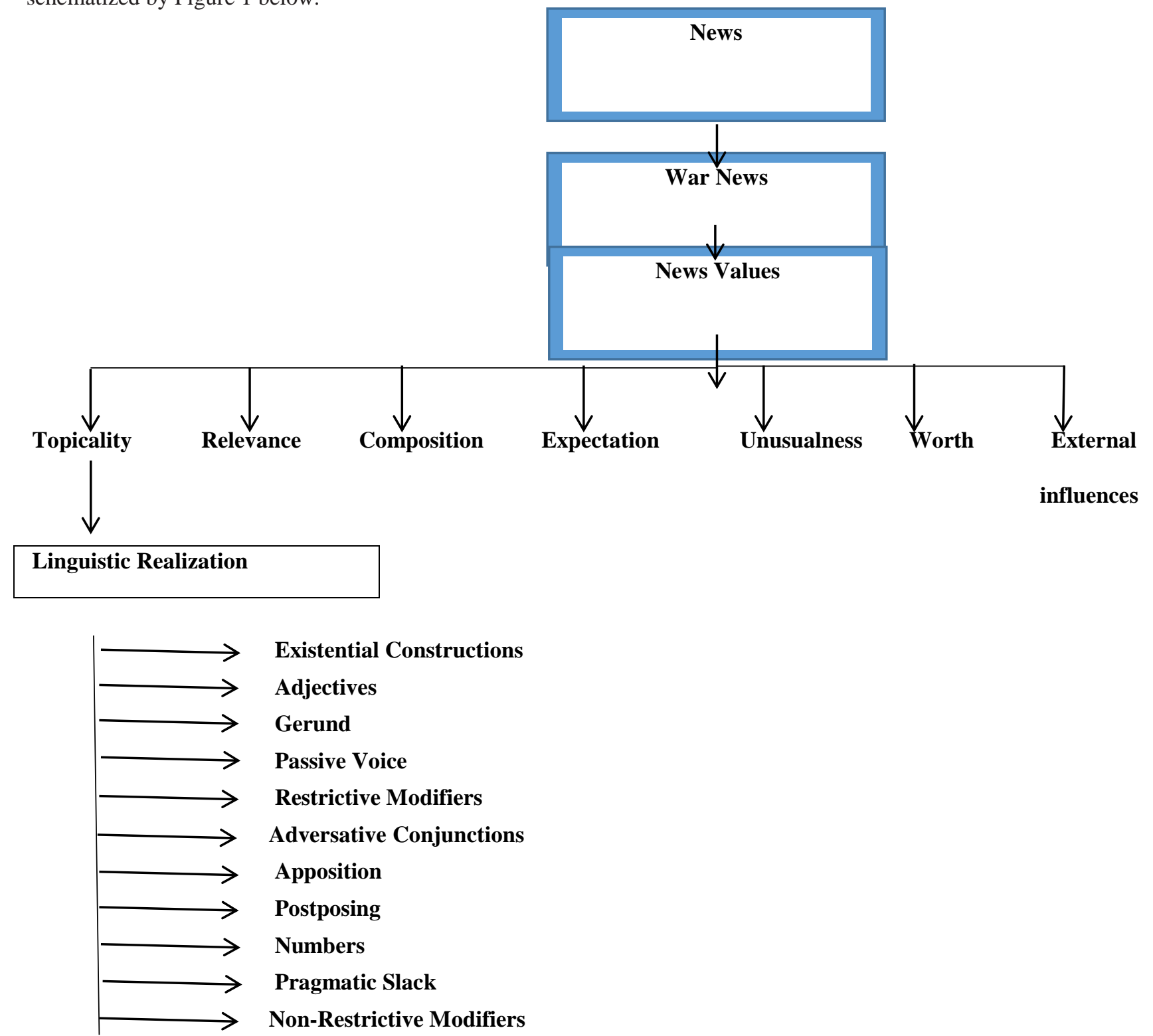

Figure 1. Pragma-Linguistic Analytical Model of Topicality 


\subsection{Pragma - Linguistic Analysis}

\subsubsection{Illustrative Analyzed Examples}

Topicality, according to (Brighton \& Foy 2007: 26), refers to new, current, immediately relevant news. However, sometimes war news is a twist, for example: Newsweek ${ }^{1}$ took a headline from a speech made by George Bush in which he said,

\section{- 'In our country, I know that there are fears of another Vietnam. Let me assure you ... this will not be another Vietnam. ${ }^{1}$ [Italics added]}

The existential construction "there are fears of another Vietnam" is characteristically used to introduce addressee-new entities into the discourse. The aim of using such construction is to draw the hearer's attention to a specific constituent within the utterance. However, the pragmatic function of existential utterances is not normally to assert the existence of some entity but "to introduce the Noun Phrase (NP) referent into the discourse world of the interlocutors by asserting its PRESENCE in a given location" (Lambrecht 1994: 179). He (ibid) considers existential sentences to be a type of presentational sentences characterized by a sentence-focus structure in which the whole sentence is 'presented' as new information.

Brighton \& Foy (2007: 26), argue that if it is not new, current, immediately relevant news, then it has no place in a newspaper or news broadcast - unless it is a new twist on an old news item. Owing to this argument, Bush's speech is based on a new twist on an old news item. It is based on what Richard Nixon (1986) and others had called the "Vietnam Syndrome". The debate over American foreign

policy had, according to Nixon, been "grotesquely distorted" by an unwillingness "to use power to defend national interests". Fear of another Vietnam, had made America "ashamed of . . . [its] power, guilty about being strong".

Following the same style of twisting, Bush boasted, as if the war had been fought for no other reason than to overcome a traumatic memory, "By God, we've kicked the Vietnam Syndrome once and for all." ${ }^{2}$ Echoing Bush's comments, the New York Times featured an article with the title, "Is the Vietnam Syndrome Dead? Happily, It's Buried in the Gulf" 3. Vietnam, the sign of American loss and division had been buried in the sands of the Persian Gulf. Kicking the Vietnam Syndrome had supposedly liberated a nation from old ghosts and doubts; had made America once again strong, whole and ready for the next war ${ }^{4}$.

Because of its being a pragmatic property, topicality can be expressed by adjectives. Colour words (an example of adjectives) are notoriously ill-matched with remote languages because of the differences in customary grouping of shades. The connotative meaning of a word is sometimes different from one country (culture) to another, for example, the 'black' refers nowadays for mourning or evil, but in old China the yellow refers to evil. Figure $\mathbf{1}$ shows how colours have denotative and connotative meanings. Also there are several reasons for examining the naming of colours.

The most striking reason for this is that one can isolate the purely descriptive meaning of colour-terms from their expressive and social meaning.

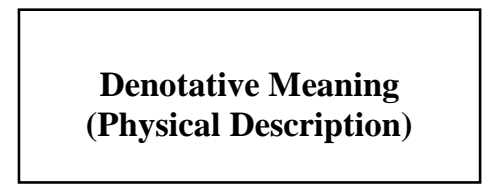

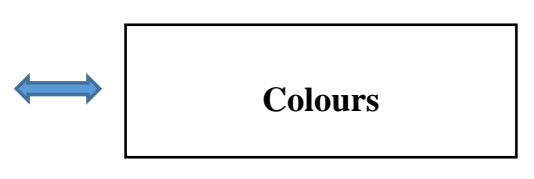

Figure 2. Colour Meaning

\author{
Connotative Meaning \\ e.g. white for purity, red \\ for danger, black for \\ mourning, .....
}

Before the beginning of the war, war news focused on the symbolism of 'yellow ribbons'. The history of the ribbons suggests that two forces were moving the practice back and forth between a symbol and a convention. The Gulf War ribbons, according to Jowett and O'Donnell (1999: 10) have descended from a similar practice during the Iran hostage crisis. The hostage crisis ended in January 1981, but eleven years later the ribbons were revived. In 1990 as U.S. troops left for Saudi Arabia, ribbons appeared on trees, utility poles, and the radio aerials of cars. The practice took on new forms, with newspapers drawing yellow ribbons banners across their mastheads and supermarkets putting pictures of ribbons on shopping bags and loading yellow tapes in their cash register. When the bombing of Iraq started, the yellow storm intensified. Hallin and Gitlin state that a Buffalo Television Channel wrapped its news desk in a larger yellow bow (cited in O'Neil,1999: 41). The largest ribbon manufacturer reported a one year sales increase from five million to fifty million yards (Larsen 1994: 12).

A first generalization about symbolism is this: a practice that appears in a conventional communication rather than in a message symbol is more flexible in acquiring new meanings.

Gulf War news was mainly concerned with a country that did not have a modern army. New York Times journalists used "gerund" to express the recent news, for example: 


"Iraqi troops stormed into the desert sheikdom of Kuwait today, seizing control of its
capital city and its rich oil-fields, driving its ruler into exile, plunging the strategic Persian Gulf region into crisis and sending tremors of anxiety around the world." 5

Rihs (2012) states that the hearer systematically elaborates a representation of the eventualities where the gerund has the function of setting a temporal framework for the main clause. The gerund enables a pragmatic adjustment. This pragmatic adjustment is based on some predicates" ability to extend their temporal denotation. Therefore, "gerund" reflects a pragmatic principle associated with the expression of event frequency and event of immediacy.

Pragmatically speaking, passive form can be used to express topicality. The relation between the logical subject and the logical object is pragmatically expected; when it is reversed, it is contrary to expectation (Herriot, 1969: 166). It can also be argued that passive construction is used when journalists wish to emphasize logical object by placing it first in order, that is, journalists wish to emphasize the unexpected (the new). For example:

\section{- Casualties are believed to have been light - nobody was killed, and only a few people injured. ${ }^{6}$}

In short passive, the subject is omitted. The subject of the short variety may be discourse-old information. Thus, focusing should be on discourse - new information, "nobody was killed", "only a few people injured." In this manner, many of the short passives, like those in the previous example, serve to avoid making explicit reference to the writer, and this is widely believed to give writing a more objective flavor (Huddleston \& Pullum, 2002: 1444).

Topicality can also be expressed through restrictive modifiers. Grammatical structure in which dependent clause modifies another element in a way which is essential to the meaning of the sentence. In other words, it is important to note however, that if you took it out, it would change the meaning of the sentence somehow. These types of modifiers limit or restrict the part of the utterance which they modify.

\section{- Initial reports that one of the missiles had a chemical warhead were quickly proved wrong. ${ }^{7}$}

It is suggested that restrictive modifiers generally invite inferences about a contrastive set of referents pragmatically (Altmann and Steedman, 1988: 193). It has been shown that people are very sensitive to the pragmatic cues of restrictive modifiers: restrictive modifiers perform a discourse function to distinguish the set of referents that possess the property described by the modifier and the set that does not. Such discourse principles are active in parsing because interlocutors engaged in a discourse interaction adhere to the general communicative principle that the exchange of information should be as informative as it needs to be (Grice, maxim of quantity, 1975).

Journalists realize that topicality of war news is not a story or an anecdote. Rather it is something that has for the person who hears or reads it an interest that is pragmatic rather than appreciative. Thus, they sometimes join two utterances to indicate newness of war news. It is however, important to note the pragmatic limitations of adversative Conjunctions that are used to express comparison or contrast between sentences, "but" is one of these adversative conjunctions, for example:

\section{- Air raid sirens went off again this evening amid fears of a second Scud attack, but they were swiftly followed by an all-clear as it proved to be a false alarm ${ }^{8}$}

Fraser (1999: 938) points out that discourse markers are a type of commentary pragmatic markers which signals a sequential discourse relationship. In other words, discourse markers "impose a relationship between some aspect of the discourse segment they are a part of, call it S2, and some aspect of a prior discourse segment, call it S1". Besides, Fraser (1990: 388) has observed that the more general the constraint imposed by a discourse connective, the more difficult it is to analyse. He has suggested that 'but' is the most general of the contrastive

discourse markers in the sense that it 'imposes the least restrictions on the relationship between S2 and the S1 with which it is contrasted' (ibid).

What is more, according to Halliday and Hassan (1976: 250), the meaning of the adversative relation is "contrary to expectation". The expectation may be derived from the content of what is being said, or from the pragmatic communicative process, in a speaker / hearer situation.

Apposition is another linguistic choice which is used to refer to topicality. Quirk et al. (1972: 515) maintain that apposition is more like coordination because typically the two or more units in apposition are constituents of the same level, for example:

- The American President, George Bush, issued an appeal to Israel to hold back from retaliation for the attack. ${ }^{9}$

- US Defence Secretary, Dick Cheney, said the operation appeared to have gone "very well". 10

Meyer (1978: 120) considers that U1 (e.g. The American President) and U2 (e.g. George Bush) may belong to the same or to different form classes. He adds that there are three types of criteria (constraints): syntactic, semantic and pragmatic. As far as the aims of this paper are concerned, the criteria of pragmatic constraints will be examined here. Meyer (ibid) suggests that in journalistic style, the reason why the attributive and designative appositions are so 
common is that they serve to provide to general audience further information about persons: not only their names but their ranks, occupations, and relations to other people as well.

Not only apposition, but also postposing is used to show topicality. An element is said to be postposed when it appears to the right of its basic position, at the end of the clause:

\section{- Two hours after the raids began, President George Bush made a televised address. ${ }^{11}$}

The canonical (non-postposing) form is:

\section{- President George Bush made a televised address two hours after the raids began}

Huddleston \& Pullum (2002: 1382-1384) argue that the postposed elements here are respectively subject, predicative complement. Pragmatically, one major factor that motivates postposing is weight: there is a tendency or preference for heavy constituents to appear late in the clause. The felicity of a postposing depends not only on the weight of the postposed constituent but also on its relative weights and the constituent over which it is moved. Postposing of 'subject + predicative' construction represents heavy and discourse-new information.

To examine the issue from the angle of topicality, there are, in this regard, pragmatic contributions to the interpretation of number words, for example:

- The Gulf War Allies have sent hundreds of planes on bombing raids into Iraq, at the start of Operation Desert Storm. ${ }^{12}$

- At least 400 raids took place. Latest reports say all the Allied aircraft have returned home safely, although France says four of its planes were hit. ${ }^{13}$

- Meanwhile, the Allied air bombardment of Iraqi military targets is continuing at the rate of 2000 sorties a day. ${ }^{14}$

In terms of their pragmatic properties, a number of expressions (hundreds, 400, 2000), can be used to give rise to the so called scalar implicatures. Papafragou and Musolino (2002: 1) state that scalar implicatures arise when a speaker uses a strong member of the numerical scale in order to implicate the stronger term. On this basis it may be inferred that scalars can receive an upper bound interpretation via a process of pragmatic inference. This inference is motivated by the listener's implicit expectation that the speaker will make his contribution to the conversation "as informative as is required" (Grice's 1975 Maxim of Quantity).

Pragmatic slack does not have an effect on topicality of war news. Lasersohn (1999: 522) points out that it is a truism that people speak 'loosely', that is, they often say things that can be recognized as untrue in a certain sense, but which can be close enough to the truth for practical purposes. For example:

- Initial reports from General Schwarzkopf are that our operations are proceeding according to plan. ${ }^{15}$

People speak with varying degrees of precision, and often speak quite loosely (pragmatic slack). In other words, Schwarzkopf does not use certain expressions, such as those including exactly, all and perfectly, appear to serve as signals of the intended degree of approximation to the truth. Thus, both utterance constructions carry the sense of topicality:

a. Initial reports from General Schwarzkopf are that our operations are proceeding according to plan.

b. Initial reports from General Schwarzkopf are that our operations are exactly proceeding according to plan.

It should be admitted here that he is, Schwarzkopf, strictly speaking, RIGHT. In spite of the fact that his speech is a little loose, he is telling the truth, and he is 'close enough' to the truth for practical purposes.

War news sometimes does not have a certain sense of topicality, for example:

- Iraq has attacked two Israeli cities with Scud missiles, prompting fears that Israel may be drawn into the Gulf War. .... Tel Aviv, and Haifa were hit in the attacks. ${ }^{16}$

The reason behind such non-topicality is the use of non-restrictive modifiers, "Tel Aviv" and "Haifa" are predictable, i.e. readers can anticipate upcoming material that is predicted from previous discourse "two Israeli cities". What is more, non-topicality does not only exist just because of predictability, but also because this piece of news is characterized by:

a. Salience: assumed to be directly in the immediate consciousness of participants

b. Shared knowledge: piece of information known to the participants 


\section{Old Information}

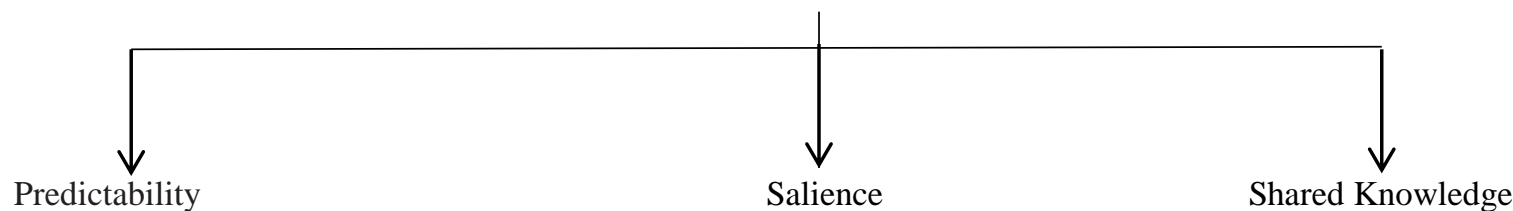

Figure 3. Non-topicality

\subsubsection{Statistical Analysis}

The Chi - Squared Test was chosen here.. The procedures of using this test depend on the comparison between the actual observed numbers (frequencies) in the text, and those numbers that we expect. In addition, the difference between observed and expected numbers should be taken into consideration according to the following formula:

$(\mathbf{O}-\mathbf{E})^{2}$

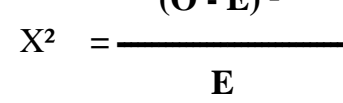

Where $O=$ observed frequency and $E=$ expected frequency.

While we were examining topicality of war news, we were interested in deducting how linguistic choices were distinguished throughout investigation. Table $\mathbf{2}$ shows how the researchers calculate the frequencies of BBC, New York Times, and News Week linguistic choices that were used to express topicality.

Table 2. Frequencies of observed, expected, difference, and significant numbers

\begin{tabular}{|c|c|c|c|c|c|}
\hline $\begin{array}{l}\text { Topicality linguistic } \\
\text { realizations }\end{array}$ & $\begin{array}{l}\text { Observed and } \\
\text { Expected Numbers }\end{array}$ & $\mathrm{BBC}$ & $\begin{array}{l}\text { New York } \\
\text { Times }\end{array}$ & News Week & Total \\
\hline \multirow{4}{*}{ Existential Utterances } & Observed & 8 & 4 & 5 & \multirow{4}{*}{17} \\
\hline & Expected & 6.33 & 5.29 & 5.29 & \\
\hline & Difference & 0.44 & 0.31 & 0.10 & \\
\hline & significance & 0.56 & 0.69 & 0.90 & \\
\hline \multirow{5}{*}{ Gerund } & Observed & 4 & 10 & 8 & \multirow{5}{*}{22} \\
\hline & Expected & 8.19 & 6.85 & 6.94 & \\
\hline & & & & & \\
\hline & Difference & 2.14 & 1.44 & 0.16 & \\
\hline & significance & -1.14 & -0.44 & 0.84 & \\
\hline \multirow{4}{*}{ Passive Voice } & Observed & 33 & 27 & 19 & \multirow{4}{*}{79} \\
\hline & Expected & 29.42 & 24.62 & 24.94 & \\
\hline & Difference & 0.43 & 0.23 & 1.4 & \\
\hline & significance & 0.57 & 0.77 & -0.4 & \\
\hline \multirow{4}{*}{ Restrictive Modifiers } & Observed & 7 & 4 & 8 & \multirow{4}{*}{19} \\
\hline & Expected & 7.07 & 5.92 & 6 & \\
\hline & Difference & 3.39 & 0.62 & 0.66 & \\
\hline & significance & -2.39 & 0.38 & 0.34 & \\
\hline \multirow{4}{*}{ Adversative Conjunctions } & Observed & 5 & 3 & 5 & \multirow{4}{*}{13} \\
\hline & Expected & 4.84 & 4.05 & 4.10 & \\
\hline & Difference & 0.005 & 0.27 & 0.19 & \\
\hline & significance & 0.99 & 0.73 & 0.81 & \\
\hline
\end{tabular}


Table 2. (continued)

\begin{tabular}{|c|c|c|c|c|c|}
\hline $\begin{array}{l}\text { Topicality linguistic } \\
\text { realizations }\end{array}$ & $\begin{array}{l}\text { Observed and } \\
\text { Expected Numbers }\end{array}$ & $\mathrm{BBC}$ & $\begin{array}{l}\text { New York } \\
\text { Times }\end{array}$ & News Week & Total \\
\hline \multirow{4}{*}{ Apposition } & Observed & 8 & 4 & 11 & \multirow{4}{*}{23} \\
\hline & Expected & 8.56 & 7.17 & 7.26 & \\
\hline & Difference & 0.03 & 1.40 & 1.92 & \\
\hline & significance & 0.97 & -0.4 & -0.92 & \\
\hline \multirow{5}{*}{ Postposing } & Observed & 9 & 7 & 5 & \multirow{5}{*}{21} \\
\hline & Expected & 7.82 & 6.54 & 6.63 & \\
\hline & Difference & 0.17 & 0.03 & 0.40 & \\
\hline & significance & 0.83 & 0.97 & & \\
\hline & & & & 0.60 & \\
\hline \multirow{4}{*}{ Numbers } & Observed & 3 & 5 & 3 & \multirow{4}{*}{11} \\
\hline & Expected & 4.09 & 3.42 & 3.47 & \\
\hline & Difference & 0.29 & 0.72 & 0.06 & \\
\hline & significance & 0.71 & 0.28 & 0.94 & \\
\hline \multirow{4}{*}{ Pragmatic Slack } & Observed & 2 & 4 & 3 & \multirow{4}{*}{9} \\
\hline & Expected & 3.35 & 2.80 & 2.84 & \\
\hline & Difference & 0.54 & 0.51 & 0.009 & \\
\hline & significance & 0.46 & 0.49 & 0.99 & \\
\hline \multirow{4}{*}{ Non-Restrictive Modifiers } & Observed & 13 & 9 & 11 & \multirow{4}{*}{33} \\
\hline & Expected & 12.29 & 10.28 & 10.42 & \\
\hline & Difference & 0.04 & 0.15 & 0.03 & \\
\hline & significance & 0.96 & 0.85 & 0.97 & \\
\hline Total & & 92 & 77 & 78 & 247 \\
\hline
\end{tabular}

Figures 4, 5, and $\mathbf{6}$ demonstrate the concluded distribution of pragmatically motivated linguistic choices used in BBC News Satellite channel, New York Times, and News Week:

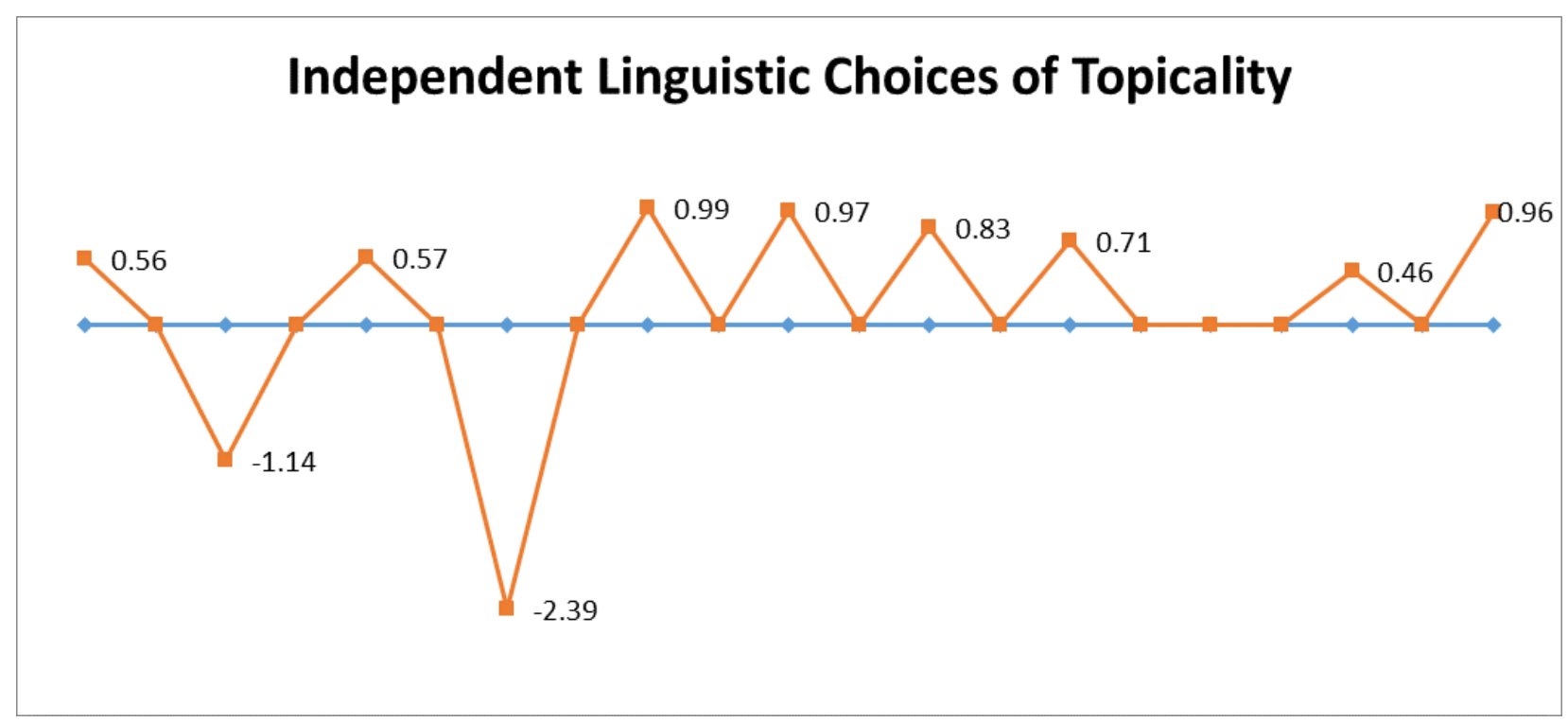

Figure 4. Percentages of Linguistic Choices of Topicality Used in BBC 


\section{Independent Linguistic Choices of Topicality}

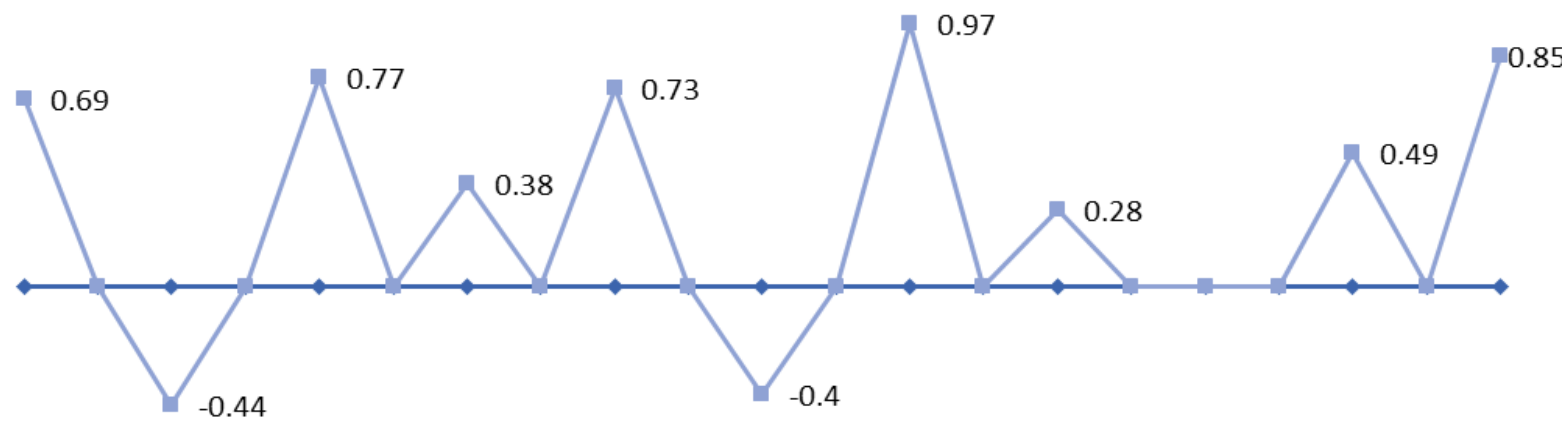

Figure 5. Percentages of Linguistic Choices of Topicality Used in New York Times

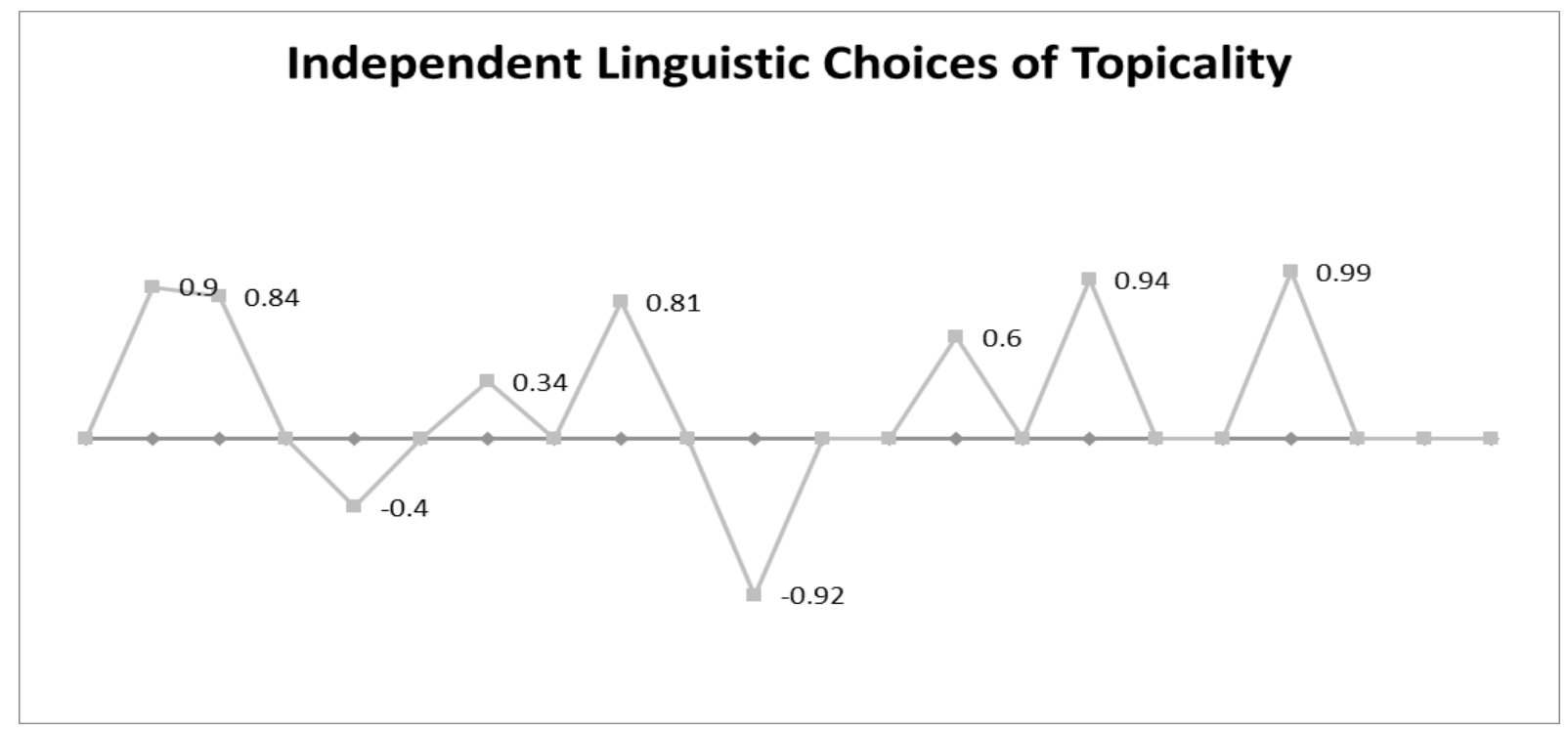

Figure 6. Percentages of Linguistic Choices of Topicality Used in News Week

In normal English, "significant" means important, while in Statistics "significant" means probably true (not due to chance). To find the significance level, subtract the number shown from one. For example, a value of ".01" means that there is a $99 \%(1-.01=.99)$ chance of it being true.

The statistical analysis shows that the use of existential utterances in BBC News Satellite channel, New York Times, and News Week is significant. The scale of significance is different. News Week is $90 \%$, New York Times is $69 \%$, and $\mathrm{BBC}$ is $56 \%$. There is no significance in the use of gerund in BBC $(-1.14 \%)$ and in New York Times $(-0.44 \%)$, but it is significant in News Week (84\%). Passive voice is significant in BBC (57\%) and in New York Times (77\%), but it is not significant in News Week (-0.4\%). Restrictive Modifiers is not significant in BBC (-2.39\%), but it is significant in New York Times (38\%) and News Week (34\%). Adversative Conjunctions is significant in in BBC (99\%), New York Times $(73 \%)$ and News Week (81\%). Apposition is significant in BBC (97\%), but it is not significant in New York Times ($0.4 \%)$ and in News Week (-0.92\%). Postposing is significant in BBC (83\%), New York Times (97\%), and News Week (60\%). Numbers is significant in BBC (71\%), New York Times (28\%), and News Week (94\%). Pragmatic slack is significant in BBC (46\%), New York Times (49\%), and News Week (99\%). Finally, Non-Restrictive Modifiers is significant in BBC (96\%), New York Times (85\%), and News Week (97\%).

To sum up, the ratio of significance of using grammatical structures that are pragmatically motivated is $83.33 \%$, but non-significance ones are $16.67 \%$.

\section{Conclusion}

In general, languages lay out a wide range of strategies for the expression of information structure, with aspects from various areas of grammar, i.e. the principle of the existence of a close correlation between information structure and syntactic properties. Hence, different information structures may reflect syntactic differences, and particular syntactic features may be the manifestation or the correlates of distinctive information-structure notions. The analytical model suggested by this study has proved to be workable in pragmatically analyzing topicality and the linguistic structures used for realizing it. As it has successfully revealed, many pragmatic implications associated with those linguistic structures as illustrated below: 
1. The existential construction is used to introduce addressee-new entities to the discourse.

2. Topicality can be expressed by the difference of pragma-cultural connotative meaning of adjectives.

3. Recent news can be revealed by pragmatic adjustment which is based on temporal denotation of gerund.

4. The pragmatic aspects of object pre-posing (new - information) in passive sentences convey topicality.

5. Topicality can be conducted by the pragmatic cues of restrictive modifiers in a discourse interaction.

6. Adversative conjunctions that are used to impose pragmatic restrictions used to transmit discourse new entities.

7. Attributive and designative appositions serve to provide audience further (new) information.

8. Pragmatic Postposing representation can be measured as heavy and as discourse-new information.

9. Topicality can be imparted by scalar implicatures of numbers.

10. Non-affective use of pragmatic slack does not affect on topicality.

11. Non-topicality can be asserted by non-restrictive modifiers.

Accordingly, the analysis conducted by this study has proved that topicality is an important element in the area of news values that should be taken into account by linguists in general and pragmatists in particular. Additionally, the hypothesis that there is a significant relationship between grammar and pragmatics which is set in the introduction of the study has been verified. In other words, the real integration between grammar and pragmatics to achieve human communication has clearly been pointed out by the analysis conducted by means of the analytical framework.

\section{References}

Altmann, G. T. M., and Steedman, M. (1988). Interaction with context during human sentence processing. Cognition, 30, 191-238.

British Broadcasting Corporation. Comprehensive and critical analysis of the 1990-1991. Available from https://www.youtube.com/watch?v=aUMAyiI0TPA

Bell, A. (1991). The Language of News Media. Oxford: Blackwell.

Berry, Nicholas. (1990). Foreign Policy and the Press: An Analysis of the New York limes' Coverage of U.S. Foreign Policy. New York: Greenwood Press.

Brighton, P. and Foy, D. (2007). News Values. London: Sage Publications.

Bunton, Kristie, Thomas Connery, and Mark Riley Neuzil. (1999). Writing Across the Media. New York: Bedford/St. Martin's Press.

Clamons, R. et al (1999). The Limits of Formal Analysis: Pragmatic motivation in Oromo grammar. In Michael et al. (eds.), Functionalism and Formalism in Linguistics. Amsterdam: John Benjamins Publishing Company.

Cuddon, J. A. (1998). The Penguin Dictionary of Literary Terms and Literary Theory. New York: Penguin Books.

Conley, D. and Lamble, S. (2006).The Daily Miracle: An Introduction to Journalism, 3rd edition. Melbourne: Oxford University Press.

Cotter, C. (2010). News Talk. Investigating the Language of Journalism. Cambridge: Cambridge University Press.

Durbin, E. and Bowlby, J. (1939). Personal Aggressiveness and War. New York: Columbia, pp. 40-48.

Farrell, M., \& Cupito, M. C. (2010). Newspapers: A complete guide to the industry. New York: Peter Lang.

Foucault, M., \& Foucault, M. (1972). The archaeology of knowledge: And, the discourse on language. New York: Dorset Press.

Fraser, Bruce. (1990). An approach to discourse markers. Journal of Pragmatics, 14, 383-95.

1999. What are discourse markers? Journal of Pragmatics, 31, 931-952

Gerbner, G., Gross L., Morgan M., \& Signorielli, N. (1986). Living with television: The dynamics of the cultivation process, in J. Bryant and D. Zillmann (eds.), Perspectives on Media Effects pp.17--40. Hillsdale, NJ: Lawrence Erlbaum Associates.

Givón, T. (2001). Syntax: An Introduction. Amsterdam: John Benjamins Publishing Company

Grabe, W. (2003). Using Discourse Representations for Reading Development. In M. Swanson \& K. Hill (Eds.), Proceeding of the 2002 JALT Conference(pp. 9-17). Tokyo, Japan: JALT Publications.

Grice H. P. (1975). Logic and conversation, in Syntax and Semantics, Vol. 3, Speech Acts, eds Cole P., Morgan J. L., editors. (New York, NY: Academic Press; ), 41-58

Haliday, M. A. K. and Hasan, R. (1976). Cohesion in English. Longman Group Limited. Hallin, D. and Gitlin, T. (1993). Agon and Ritual: The gulf war as Popular Culture. Political Communication, 10, 411-414.

Harcup, Tony and O'Neill, Deirdre (2016). What is news? Journalism Studies. DOI: 10.1080/1461670X.2016.1150193, PP. 1-20.

Herriot, P. (1969). The Comprehension of Active and Passive Sentences as a Function of Pragmatic Expectations. Journal of Verbal Learning and Verbal Behavior, 8(2), PP. 166-169.

Hoey, M. (2001). Textual interaction: An introduction to written discourse analysis. New York, NY: Routledge.

Hough, George A., 3rd. (1988). News Writing (4th edition). Boston: Houghton Mifflin Company.

Huddleston, R. and Pullum, G. (2002). The Cambridge Grammar of the English Language. Cambridge: Cambridge University Press.

Itule, Bruce D. and Douglas A. Anderson. (1991). News Writing and Reporting for Today's Media (2nd edition). Boston: McGraw-Hill. 
JACOBSON, P. and Pullum, G. (eds.). ( 1982). The nature of Syntactic Representation. Dordrecht: D. Reidel Publishing Company

Jowett, G. S., \& O'Donnell, V. (1999) Propaganda and persuasion. (3rd Ed.). Thousand Oaks, CA: Sage.

Larsen, L. (1994). The Yellow Ribbon of America, A gulf War Phenomenon. Journal of American Culture, 17, 11-22.

Lambrecht, K. (1994). Information Structure and Sentence Form. Cambridge: Cambridge University Press.

Lasersohn, Peter. 1999. Pragmatic Halos. Language 75(3), 522-551.

Lorenz, Alfred Lawrence and John Vivian. (1996). News: Reporting and Writing. Boston: Allyn \& Bacon.

Mencher, Melvin. (1997). News Reporting and Writing (7th edition). Madison, WI: Brown and Benchmark. (2006). News Reporting and Writing (10th edition). New York: McGraw-Hill.

Meyer, Ch. F. (1987). Apposition in English. Journal of English Linguistics 20(1), 101-21.

Morris, W. (1970). The American Heritage dictionary of the English language. New York: American Heritage. 1185.

Nacos, Brigitte Lebens. (1990). The Press, Presidents, and Crises. New York: Columbia University Press.

New York Times. Pentagon Report on Persian Gulf War: A Few Surprises and Some Silences. Retrieved from: http://www.nytimes.com/1992/04/11/world/pentagon-report-on-persian-gulf-war-a-few-surprises-and-some-

ilences.html?pagewanted=all

New York Times. After the war: The Presedent; Transcript of President Bush's Address on End of the Gulf War. Retrieved from: http://www.nytimes.com/1991/03/07/us/after-war-president-transcript-president-bush-s-address-endgulf-war.html

News Week magazine.

News Week magazine. Looking Back at Desert Storm. Retrieved from: http://www.usnews.com/news/articles/2016-0117/from-1991-looking-back-at-desert-storm

Niebuhr, R. (1937). Beyond Tragedy: Essays on the Christian Interpretation of History. New York: Charles Scribner's Sons.

Nixon, R. (1986). No More Vietnams. London: W. H. Allen.

O’Neil, B. (1999). Honor, Symbols, and War. Michigan: Michigan University Press.

Papafragou, A. and Musolino, J. (2002). The Pragmatics of Number. Proceedings from the 24th Annual Conference of the Cognitive Sciences Society, Hillsdale, NJ: Erlbaum.

Park, Robert E. (1940). News as a Form of Knowledge: A Chapter in the Sociology of Knowledge. American Journal of Sociology 45(5), 669-686.

Pettegree, A. (2014). The Invention of News. How the World Came to Know About Itself. New Haven: Yale University Press.

Quirk, R., S. Greenbaum, G. leech, and J. Svartvik. (1972). A Grammar of Contemporary English. London: Longman.

Rihs, A. (2012). A defence of the Overlap Criterion for Distinguishing between the French Gerund and Present Participle. In C. Nishida \& C. Russi, Building a bridge between linguistic communities of tm: NY: Rodopi, PP: 203 327.

Salmon, Lucy Maynard (1923). The Newspaper and the Historian. New York: Oxford University Press.

Schechter, D. (2003). Media Wars:News at a Time of Terror. Oxford: Rowman \& Littlefield Publishers, Inc.

Schlesinger, Ph. (1987). Putting Reality Together. London: Methuen.

Stephens, M. (1997). A history of News: From the Drum to the Satellite. New York: Viking.

van Dijk, T. (1988). News as Discourse. Hillsdale, NJ: Lawrence Erlbaum.

Weaver, D., Randal, B., Bonnie, B., Voakes, P., and G. Cleveland, W. (2007). The American Journalist in the 21st Century. Mahwah, NJ: Lawrence Erlbaum Associates.

James, W. (1910). The Moral Equivalent of War, in L. Bramson and G. W. Gathals (eds.), War: Studies from Psychology, Sociology and Anthropology, revised edn, New York: Basic Books, 1968, 21 - 31.

\section{Notes:}

1. Newsweek, 10 December 1990

2, 3, 4. New York Times, 2 December 1983

5. New York Times, August 3, 1990

6, 7. BBC on This day January| $17 \mid 1991$

8. BBC on This day January| $17 \mid 1991$

9, 10. BBC on This day January| $17 \mid 1991$

11, 12 BBC on This day January| $17 \mid 1991$

13, 14, 15. 16 BBC on This day January| 17 | 1991 